\section{The Value of Forests}

THE value of forests to mankind in their beneficial influence on climate and the protection they exert against erosion, flood disasters and the man-made desert has come to the fore of recent years as one of the serious questions of present-day administration and civilization. It has been recognized that in both the Old and the New Worlds the results of the ignorant interference with the world's formerly existing and widespread forests and the failure to understand Nature's laws and the equilibrium she maintains when left alone has resulted in the past, and is resulting at the present day, in disasters of unforeseen magnitude. In a study of the past, India can show many instances of the results of interference with Nature's delicate balance between the forest, grassland and water supplies, and in that country, as a result of seventy years of forest conservancy, the lesson of the importance of the forests to the country has been grasped to some extent by her administrators. Even the people in some localities have become aware of the value of their local forests. The wireless has now come to the assistance of the Forest Department in making this value, for varying reasons in varying localities differing in configuration, elevation, aspect and climate, generally known to the people chiefly concerned, and including the town-bred population. The Indian Forester $(63$, No. 8 ; 1937) reproduces a radio talk on forests and climate given by Sir Gerald Trevor, inspector-general of forests, from Delhi. Those with a knowledge of the Indian district and its methods of administration in the past will appreciate to the full the significance of the enormous stride from the past which such a method of forest propaganda foreshadows.

\section{Forestry in Sweden}

AN interesting historical study by Lars Tirén of forestry conditions in the Degerfors district of the province of Västerbotten has recently been published (Rep. Swedish Inst. Exp. Forestry, No. 30. Centraltryckeriet, Esselte A.-B., Stockholm). The foundation upon which the paper is based is drawn from the work of the Forestry Research Institute in the Kulbäcksliden research forest situated in the above-mentioned region in the north of Sweden at an altitude of $160-320$ metres. The history of the forest area has been traced back to the coming of human beings into north Sweden in the form of a Nordic stone age people who immigrated soon after the inland ice had receded from Västerbotten 8,000 years ago. This race had, as fishermen and hunters, already spread widely in the region by about 2,000 years B.c. The progress in development of the people is traced, and with this development the inevitable effect on the forests of the region. The influence on the forest of fires, especially the great fire of 1694, is traced, and the contrast made between the area affected by this great fire and the forest which escaped. Not the least informative parts of the paper are those dealing with tar production and potash manufacture. The production of tar in Sweden goes back to very olden times. It was known in Viking days, and tar was exported in the thirteenth century. In the seventeenth century for long periods the export amounted to 70,000-80,000 barrels annually. In the region here specially dealt with, tar production was an important article of export. Hardwoods are used in potash manufacture, and here again the industry is a very old Swedish one in which the peasantry take a prominent part.

\section{The Fairbridge Farm Schools}

The story of Kingsley Fairbridge's life-work was told at a meeting of the Royal Society of Arts on February 1 by the Hon. Sir Hal Colebatch, AgentGeneral for Western Australia, who, as a member of the Western Australian Government, saved the original Fairbridge Farm School from collapse during the Great War by arranging for a State subsidy for it. It had at first been financed wholly from private subscriptions raised by the Child Emigration Society which Fairbridge formed in 1909 while an Oxford Rhodes scholar. The purpose of the scheme was, and is, to take from unpromising if not hopeless surroundings children of 7-12 years of age and give them a good general education with special training in all phases of farm and domestic activity, up to the age of sixteen years. Their subsequent careers are self-chosen. Many do not choose farm work, but their farm training is none the less valuable to them. The Farm School method involves: residence in a cottage home restricted to fourteen inmates (boys or girls) controlled by a carefully selected house-mother, training combined with teaching, provision for leisure time occupations, an elaborate 'after-care' system, including the banking of half of all earnings up to the age of twenty-one years. Judged by results, as represented by some 700 ex-pupils, all selfrespecting self-supporting citizens, pulling their full weight in the community, the scheme has been an outstanding success. Similar schools have now been founded in Canada, Victoria and New South Wales. By the end of next year, the four schools should be in full operation with an aggregate enrolment of nearly 1,200 and an annual intake and outflow of 250 , the total cost per head being about $£ 50$ a year.

\section{Accessions to the British Museum (Bloomsbury)}

Among accessions to the British Museum (Bloomsbury) reported at the April meeting of the Trustees are two which are of outstanding interest on the history of cultural development in Great Britain. Of these the earliest and from its unique character the more arresting comes from a bronze age burial on the north Yorkshire moors. In Loose Howe, a barrow overlooking Rosedale, excavated by Dr. and Mrs. Frank Elgee, was found a coffin consisting of two canoes, with a third canoe beside it. A bronze dagger associated with this burial afforded evidence of date; but the barrow also contained secondary burials, with one of which was a polished stone axe-hammer of Danish type. Canoe-burial is a new feature in archæology. The canoes had fresh bark on them and evidently had been made expressly for the burial, 
pointing to a hitherto unknown ritual of canoe-burial. It has been suggested that such canoe-burials may have given rise to the custom of coffin burial, typical in northern England and Denmark. In view of the conservatism characteristic of later maritime forms and custom in Scandinavia, the comparison with the ship-burials of a much later period inevitably is also suggested. These antiquities are on loan to the Museum by Captain A. W. Milburn. The second object of special interest is a stud ornamented with millefiori enamel, found at Chesterholme (Vindolanda) in Northumberland in an early fourth century deposit. It has been given by Mr. Eric Birley. It is the only example of millefiori of a late Roman date as yet found in Britain. It is thought that it may, on further study, provide a link with post-Roman Celtic enamels. Bronze objects belonging to the first Babylonian dynasty, circa 2000 B.c., are additions to examples of the art of a period at present poorly represented in the Museum. They are a bronze bar decorated with a ram's head, and three small figures of women. It is probable that they come from sites near the Diyalah River in Iraq.

\section{Meteorological Observation in Certain British Colonies}

Ir may be within the recollection of many readers of NATURE that the period August 1, 1932August 31, 1933, was chosen as the Second International Polar Year, during which meteorological observations were to be made at as many places as possible in both arctic and antarctic regions in furtherance of the study of world meteorology. Since the First International Polar Year, fifty years earlier, attention had become directed more to the problem of the exchange of air between equatorial and polar regions, and for that reason corresponding observations were required from middle and lower latitudes. The Governments of several British Colonies have published the special observations made within their areas, and the Meteorological Office, Air Ministry, is supplementing these with the publication of the observations made at a number of places not included in the above-mentioned Colonies, namely, Ascension Island, St. Helena, South Georgia, Falkland Islands, Ocean Island and British Somaliland. These summaries constitute Geophysical Memoir No. 73 of the Meteorological Office (H.M. Stationery Office. 48. 6d. net). Monthly summaries of daily observations of the meteorological quantities most commonly observed are given in tabular form. These are supplemented by hourly readings in a few instances and by records of autographic instruments. The memoir contains no indication of the results of the undertaking as a whole, being only part of the observational material that is becoming available for students of the atmospheric circulation of the globe.

\section{Telephone Circuit Noise Meters}

Mr. H. R. Harbotwle of the Post Office Research Station read a paper on February 4 to the Institution of Electrical Engineers describing an instrument for measuring the disturbing effect of induction from power lines on telephones. During a meeting of the Commission Mixte Internationale held at Dollis Hill, the delegates made comparative measurements of four different types of disturbances by the American, German and valve voltmeter methods. It was agreed that the last-mentioned should be developed and that the precise specification for the actual instrument should be determined by the Comité Consultatif Internationale (the C.C.I. for telephonic communications at great distances). It has been agreed internationally to call an instrument of this type a psophometer. The latest proposals are explained by the author. He states that from comparative measurements of the induction from the Midi Railway, which is supplied with power through mercury arc rectifiers, to the overhead communication lines of the French administration, the results obtained by using the psophometer fully justify this method of making noise measurements. The British Electrical and Allied Industries Research Association has pub. lished a pamphlet $M / T 38$ describing the method of constructing a psophometer. About a year ago, a commercial model on similar lines was constructed by the General Electric Co. at Coventry. Others have been made by Siemens and Halske in Germany, by the Administration and Ericssons in Sweden, by Standard Telephones and Cables in England and by the American Telephone and Telegraph Co. At the same meeting, a paper by Dr. A. H. Davis entitled "An Objective Noise Meter for the Measurement of Moderate and Loud, Steady and Impulsive Noises" was also read. The difficulties experienced were surmounted by adopting a technique in which the noise and the reference note are listened to alternately.

\section{Carnegie Trust for the Universities of Scotland}

THE circumstances of the origin of the Trust are recalled in its recently published report for the year 1936-37. Referring to the passing of Lord Craigmyle, formerly one of the trustees, the report quotes a passage from Mr. Carnegie's autobiography which shows that it was an article contributed by the former to the Nineteenth Century magazine in 1897 that led to the idea of a gift of ten million dollars"half of the yearly revenue from it to be used to pay the fees of deserving poor students and the other half to improve the universities". Last year the Trust devoted nearly $£ 52,000$ to the payment of fees of deserving poor students-2,637 men and 897 women. Voluntary refunds of fees advanced by the Trust in previous years, that is, since 1901, amount to nearly $£ 40,000$, namely, $£ 25,000$ by 569 men and $£ 14,500$ by 454 women. Women beneficiaries would seem to be more given to expressing their gratitude in this way than men. Expenditure on post-graduation fellowships, scholarships and grants for research amounted to $£ 17,500$. Resignations of fellows and scholars for the purpose of entering upon professional careers were numerous-a sign, perhaps, of reviving prosperity. This was specially noticeable in the field of chemical research. Of thirty-four fellows and scholars in this field, thirteen were absorbed into industry before the termination of their grants. 